\title{
GROUNDWATER RECHARGE ESTIMATE AT ALTO RIO GRANDE - MG WATERSHED
}

\section{LUCAS A. DA SILVA ${ }^{1}$, ANTÔNIO M. DA SILVA ${ }^{2}$, GILBERTO COELHO ${ }^{3}$, CARLOS R. DE MELLO ${ }^{4}$, DONIZETE DOS R. PEREIRA ${ }^{5}$}

\begin{abstract}
Springs are outcrops of aquifers surface, and the water cycle in this environment pass through the recharge, generally defined as the amount of water added to the aquifer, which may occur locally from rainwater infiltration. This study uses the Water Table Fluctuation (WTF) method to estimate the direct recharge and a groundwater balance to estimate the deep recharge on unconfined aquifers. The WTF method employs data of the aquifer water levels and its specific yield to estimate the direct recharge. The groundwater balance considers the direct recharge estimated by the WTF method, as the water input in the system and outputs as the base flow and deep recharge. The recharge was estimated at four areas at the watershed of Alto Rio Grande city, Minas Gerais (MG) state, in Brazil. The direct recharge estimate was $121.11 ; 64.62 ; 83.99 ; 152.46$ ( $\mathrm{mm} /$ year) for the L1, L2, M1 and M2 areas. The effect of the presence of forest in the recharge area can prevail over slope of relief, allowing more direct recharge, even in sources with steeper relief. The runoff from the springs in the study period exceeded the direct recharge, indicating a situation in which the saturated zone feeds the vadose zone. The annual flow was above the direct recharge pointing a situation of over exploitation of the aquifer, a non sustainable situation. The specific yield of the aquifers could also have been underestimated.
\end{abstract}

KEYWORDS: Groundwater recharge; Aquifer surface; Springs.

\section{RECARGA DE AQUÍFEROS SUPERFICIAIS NA REGIÃO DO ALTO RIO GRANDE-MG}

RESUMO: As nascentes são afloramentos dos aquíferos superficiais, e o ciclo da água neste ambiente passa pela recarga que é definida, de maneira geral, como a quantidade de água que é acrescentada ao aquífero, podendo ocorrer localmente a partir da infiltração das águas das chuvas. Neste trabalho, apresenta-se o método de flutuação das superfícies livres (Water Table FluctuationWTF) para estimativa da recarga direta e um balanço hídrico subterrâneo para estimativa da recarga profunda, em aquíferos livres. O método WTF utiliza dados de monitoramento do nível do aquífero e rendimento específico do aquífero para a determinação da recarga direta. O balanço hídrico subterrâneo assume a recarga direta estimada pelo método WTF como sendo a entrada de água no sistema, e as saídas, como sendo o escoamento de base e a recarga profunda. As estimativas de recarga foram aplicadas a quatro áreas de recarga de aquíferos superficiais da região do Alto Rio Grande-MG. A estimativa da recarga direta foi de 121,11; 64,62; 83,99 e 152,46 (mm/ano) para as áreas L1, L2, M1 e M2. O efeito da presença de mata na área de recarga pode prevalecer sobre o da declividade do relevo, proporcionando maior recarga direta, mesmo em áreas de recarga com relevo mais íngreme. A drenagem do aquífero superficial (deflúvio propiciado pelas nascentes) no período avaliado superou a recarga direta, indicando uma situação em que a zona saturada, alimenta a zona vadosa.

PALAVRAS-CHAVE: Recarga hídrica, Aquífero superficial, Nascentes.

\footnotetext{
${ }^{1}$ Doutorando em Recursos Hídricos em Sistemas Agrícolas - Universidade Federal de Lavras.

${ }^{2}$ Professor, Departamento de Engenharia - Universidade Federal de Lavras.

${ }^{3}$ Professor, Departamento de Engenharia - Universidade Federal de Lavras.

${ }^{4}$ Professor, Departamento de Engenharia - Universidade Federal de Lavras.

${ }^{5}$ Professor, Instituto de Ciências Agrárias, Campus Florestal - Universidade Federal de Viçosa.

Recebido pelo Conselho Editorial em: 9-4-2010

Aprovado pelo Conselho Editorial em: 17-6-2012
} 


\section{INTRODUCTION}

The quantification of groundwater reserves is an important issue in social and economic development, making it a priority to water resource management agencies. In this context, the quantification of groundwater recharge is a basic prerequisite for an efficient management of water resources. This is particularly vital in semiarid regions and areas where there is overexploitation, since such resources are often the key to economic development (BARRETO, 2006).

The main source of aquifer recharge is the rain that can penetrate the soil and percolate directly into the groundwater zone (FAZAL et al., 2005). The effectively infiltrated water is not necessarily the result of a single rain event, but may represent a series of events preceding rainfall (PAIVA, 2006). Depending on the characteristics of the aquifer, part of the infiltrated water may cause a rise in the groundwater level and, consequently, an increase in the gradient of discharge. According to this author, the groundwater recharge may also occur by infiltration from rivers, canals and lakes and phenomena induced by human activities, such as irrigation and urbanization.

The aquifer systems are dynamic and continuously adjust themselves to short and long-term changes in climate, exploitation, patterns of changes of rivers and their exploitation, and land use (WENDLANDET al., 2007). The monitoring of water levels in aquifers, in observation wells, provides essential data for assessing the dynamics of this important resource (recharge, storage and discharge of the aquifer). Monitoring is important for the development of models to predict trends, design, implement and monitor the effectiveness of management and aquifer protection programs. Among the methods for estimating groundwater recharge, stand out of the Water Balance and the Free Surface Fluctuation methods.

\section{Water Balance Method}

The stages of the water cycle, occurring within regions of interest, can be accounted by a water balance, and this presents great spatial variability. The water balance involves quantifying the components of the control system in a predetermined volume control, aiming at its best understanding, based on the principle of conservation of mass and energy exchange of the systems involved in time and space (ZAKIA, 1987; TUCCI \& BELTRAME 2007). The conservation of mass for certain volume control means that the rate of variation mass stored is the same as the difference between the sum of the amounts of water entering and leaving in a given time interval (MENDONÇA, 2003). The watershed, when used as control volume, is the key element in the analysis of the hydrological cycle.

The water balance (Figure 1) for a given control volume can be described as hydrological:

$$
P_{\mathrm{ef}}+\mathrm{Q}_{\mathrm{e}}=\mathrm{ET}+\mathrm{Q}_{\mathrm{s}} \pm \Delta \mathrm{S}
$$

in which, $\mathrm{P}_{\mathrm{ef}}$ is effect precipitation; $\mathrm{Q}_{\mathrm{e}}$ and $\mathrm{Q}_{\mathrm{s}}$ are the water flows entering and leaving the system, respectively; ET is evapotranspiration and $\Delta \mathrm{S}$ is variation of water storage on the ground, in a given time period, which is adopted in relation to interests and data availability (BARRETO, 2006 \& MELLO, 2003). The components of the water cycle to be represented on the water balance equation (Equation 01) depend on the established limits, in the same way as the representative magnitudes of such components should be employed in compatible units, either volumetric $\left(\mathrm{L}^{3}\right)$, discharge $\left(\mathrm{L}^{3} \mathrm{~T}^{-1}\right)$ or blades (L). 


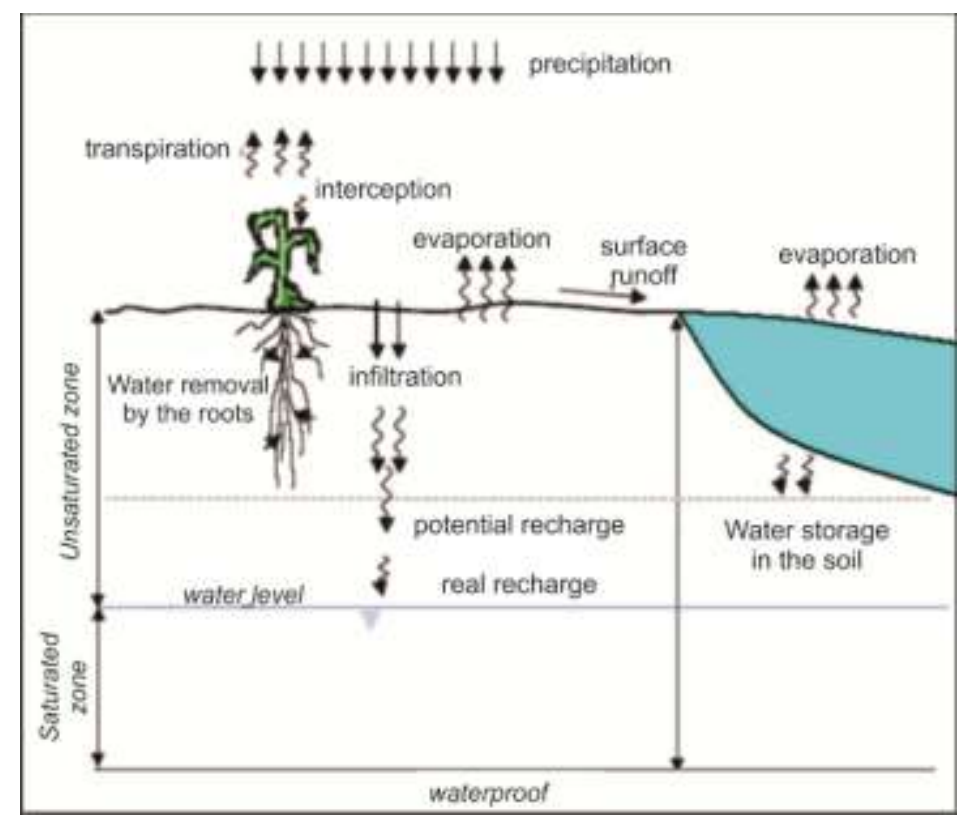

FIGURE 1. Components of hydrological cycle for water balance (BARRETO, 2006).

According to BARRETO (2006), by dividing the volume control (underground) into subcomponents, you can rewrite the equation of water balance differentiating the saturated zone $(z s)$ and the unsaturated zone $(n s)$, and in this case, the components Qe, Qs, ET and $\Delta$ s may have subcomponents in both regions.

For the saturated zone, the equation can be written as (SCHICHT \& WALTON, 1996; SCANLONET al. 2002):

$$
\mathrm{R}_{\mathrm{p}}=\Delta \mathrm{S}^{z s}+\mathrm{q}_{\mathrm{b}}+\mathrm{ET}^{z s}-\mathrm{Q}_{\mathrm{s}}^{z s}+\mathrm{Q}_{\mathrm{e}}^{z s}
$$

in which $R_{p}$ is deep recharge; $\Delta S^{z S}$ is storage variation in the saturated zone; $\mathrm{q}_{b}$ is the flow of base drained by effluent; $\mathrm{ET}^{\mathrm{zS}}$ is the underground evapotranspiration and $\mathrm{Q}_{\mathrm{s}}^{\mathrm{zS}}$ and $\mathrm{Qe}_{\mathrm{e}}^{\mathrm{zS}}$ is the subsurface flow of the study area and includes pumping effects, and all variable expressed as rate $\left(\mathrm{LT}^{-1}\right)$.

The major advantage of the water balance method lies in the use of data that are generally available (precipitation, surface runoff and water levels) (WENDLAND et al., 2007). However, according to SCANLON et al. (2002), the biggest limitation of the water balance method is that the precision of the estimate of recharge depends on the accuracy with which the components of the equation were measured or estimated. It should be noted that in any case involving the quantification of information, the accuracy of the data collected is a desirable and necessary requirement, and the designation made by SCANLON et al. (2002) is not a limitation but rather a requirement for a good estimate of the recharge water balance method.

\section{Method of Free Surface Fluctuation}

The Method of Free Surface Fluctuation (WTF - Water Table Fluctuation) is the most used technique for estimating recharge (MAZIERO, 2005). The WTF method is applicable only to free aquifers and requires knowledge of the specific yield of the geological formation (Sy) and variations in the water level over time (BARRETO, 2006). According to BERTOL (2007), the best results are obtained in areas with shallow water level, enabling rapid increases with rainfall, since deep levels tend not to show great variation. The accuracy of the measurements is of great importance because the blade of the precipitated water at each event may comprise a few tens of millimeters and its effect on the water level is small (WAHNFRIED \& HIRATA, 2005).

According to WAHNFRIED \& HIRATA (2005), the greatest advantage of the recharge evaluation by the model WTF is its simplicity, since it is not necessary to consider the transport 
mechanisms governing the passage of water into the unsaturated zone, enabling disregard, for example, the existence of preferential flow paths. However, to use this model, you need to consider some aspects, since many phenomena related to natural changes (climate) and anthropogenic activities (use and occupation of land) for decades cause oscillation of the water level along time.

The WTF method assumes that the increases in water levels in shallow aquifers are due to water (groundwater recharge) that reaches the free surface of the aquifer. Recharge is calculated as follows (HEALY \& COOK, 2002; SCANLON et al., 2002; WAHNFREID \& HIRATA, 2005):

$$
\mathrm{R}_{\mathrm{d}}=\mathrm{S}_{\mathrm{y}} \cdot \frac{\mathrm{d}_{\mathrm{h}}}{\mathrm{d}_{\mathrm{t}}}=\mathrm{S}_{\mathrm{y}} \cdot \frac{\Delta_{\mathrm{h}}}{\Delta_{\mathrm{t}}}
$$

in which $\mathrm{R}_{\mathrm{d}}$ is the direct recharge $\left(\mathrm{LT}^{-1}\right), \mathrm{S}_{\mathrm{y}}$ is the aquifer specific yield (dimensionless); $\mathrm{h}$ is the groundwater level $(\mathrm{L})$, and $\mathrm{t}$ is time $(\mathrm{T})$.

The specific yield of a free aquifer is virtually equal to the storage coefficient, being of the order of the useful porosity of the medium (BARRETO, 2006). The useful porosity may be understood as the ratio between the volume of water draining by gravity from a soil initially saturated with water, at an infinite time, and the total volume of the porous medium. In Equation 03, it is assumed that water that reaches the water table level immediately comes into storage and all other components of the underground water balance (evapotranspiration underground flow basis, input and output subsurface flow) are null during the recharge (WENDLAND et al., 2007).

HEALY \& COOK (2002) determined that the application of Equation 03 for all individual elevations of water level determine an estimate of the full charge, and $\Delta \mathrm{h}$ is equal to the difference between the rise peak and the lowest point in the curve of antecedent recession. The antecedent recession curve is the trace that the level of the observation well of the aquifer would have followed in the absence of high water level (Figure 2). This extrapolation is subjective and tries to accommodate the lag between the beginning of the precipitation and the consequent start of level variation, resulting from the natural flow through the unsaturated zone (BARRETO, 2006).

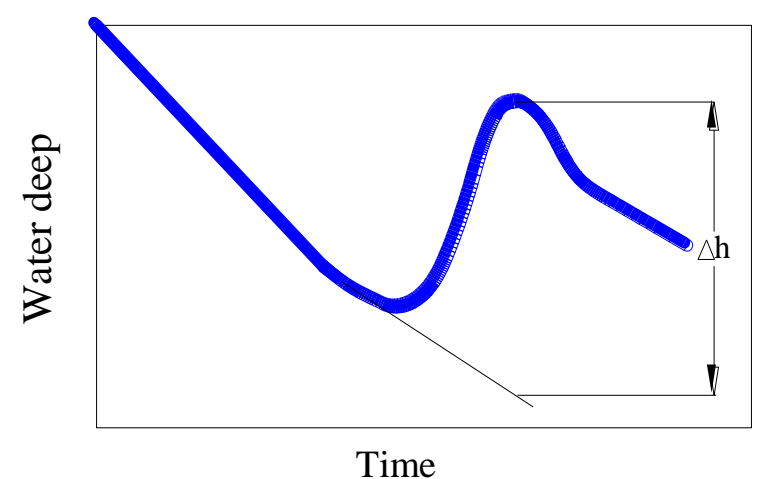

FIGURE 2. Extrapolation of water recession curve to estimate the total flow, where $\Delta \mathrm{h}$ is the difference between the rise peak and the lowest point of the antecedent curve of recession (BARRETO, 2006).

There is a variety of methods to estimate recharging. Such methods estimate over multiple scales of time and space and can be used in a range of complexities and adversities (HEALY \& COOK, 2002). BARRETO (2006) reports that, although most methods provide valuable information about recharging, they are not always directly applicable. These methods are iterative and involve continual refinements of recharge rate when additional data are collected.

In this context, this paper presents the estimation of direct groundwater recharge through the Free Surface Fluctuation method (Water Table Fluctuation - WTF) and the deep recharge through a underground water balance in 2008, in four recharge areas of the springs the Alto Rio Grande region, Minas Gerais (MG) state. 


\section{MATERIAL AND METHODS}

\section{Characterization of the experimental area}

The study was conducted in two sub-basins included in the Water Resources Planning and Management Unit of the Alto Rio Grande (UPGRH-GD1) in Minas Gerais, chosen based on previous hydrological studies (SILVA et al., 2005); and in each of these sub-basins it was studied two areas of shallow groundwater recharge.

The first study area corresponds to sub-basin of Ribeirão Lavrinhas, located in the city of Bocaina, Minas-MG, which empties directly into the Rio Grande and is an area of cambisols. The second study area corresponds to the sub-basin of Ribeirão Marcela, which empties into Córrego Jaguara, which flows directly into the reservoir Camargos/CEMIG HPP, located in the city of Nazareno, MG, area of Latosols.

In sub-basin of Ribeirão Lavrinhas it was monitored springs L1 (punctual) and L2 (diffuse). The recharge area of the L1 spring was estimated at 7.24ha, whose average slope of the land is $28.7 \%$, average elevation of $1,668.4 \mathrm{~m}$, and the use and occupation of land comprises $92.9 \%$ of pasture, $6.9 \%$ of wild ferns and $0.2 \%$ of forests. The recharge area of the L2 spring was estimated at 8.74ha, average slope of the land is $54.2 \%$, average elevation of $1,321.6 \mathrm{~m}$, and the use and occupation of land comprises $68.7 \%$ of pasture , $28.7 \%$ of wild fern, $2.1 \%$ of forests and $0.5 \%$ of marsh. In sub-basin of Ribeirão Marcela, it was monitored M1 and M2 springs, both characterized as diffuse. The recharge area of the M1 spring was estimated at 9.14ha, with an average slope of the land of $15.6 \%$ and an average elevation of $1,035.2 \mathrm{~m}$, and the use and occupation of land comprises $66.7 \%$ of pasture; $22.4 \%$ of corn, $7.8 \%$ of others, corresponding to the area of the BR 265 highway, $2.9 \%$ by a floodplain where it starts draining the aquifer forming the tax and $0.2 \%$ over an area of native forest, which is very thin and sparse. The recharge area of the M2 spring was estimated at 8.45ha, having an average slope of the land of $25.4 \%$ and an average elevation of $1.026 .8 \mathrm{~m}$, and the use and occupation of land comprises $48.5 \%$ of native forest, $33.2 \%$ of pasture, $10.2 \%$ of corn, $6.0 \%$ of floodplain and $2.2 \%$ of others, which are carriers for the management and disposal of production of corn.

During the field stages, it is possible to see that in all monitored sources there is a form of intervention that alters the physical characteristics of their APPs, thus not meeting the environmental regulations in the country. The most common forms of action constitute the use of these fields for grazing without soil conservation practice, and watering cattle (characterized by trampling and manure), occurring even a frequent practice of weeding and even burnt, hillsides above the site of upwelling water.

\section{Instrumentation of spring recharges areas}

In October 2007, wells were drilled in recharge areas from each spring (11 for L1, 15 for L2 and 17 wells for M1 and M2) for monitoring the level of the superficial aquifer. The distribution of these depended on the topography of each area and depth limitation of the Dutch auger drilling $(4 \mathrm{~m})$ used in the operation. The monitoring of the flow of the springs was done using WSC flume, with biweekly frequency (the same as the water level of the aquifer), from February 2008 to January 2009.

The depth of the surface level of groundwater in each well at each recharge area was measured with a measuring tape and then converted to altitude by subtracting the aquifer depth level of the reference topographical elevation of each well in each one. Subsequently, these altitude data were spatialized via SIG ArcGIS ${ }^{\circledR}$ version 9.2, thus generating a surface model of the aquifer level for each monitored location and monitoring performed. With the model of surface level of the aquifer it was generated altimetric class maps of the aquifer level at intervals of $50 \mathrm{~cm}$ and it was calculated the areas of each class. Thus, from Equation 04, it was obtained the average elevation of the aquifer in each monitoring interval: 


$$
A_{M}=\frac{\sum_{i=1}^{n}\left(e_{i} \cdot a_{i}\right)}{\sum a_{i}}
$$

where $A_{M}$ is the average height; $e_{i}$ is the average elevation between two consecutive altimetric classes and $a_{i}$ is the area of each class. The set of values of $A_{M}$ was the time series of medium altitudes in the aquifer monitoring period.

The flow rates of the springs are fed by the draining of surface aquifers constituting the base flow, which, in turn, depends on the amount of water stored in the aquifers and their transmission properties of the water, exponentially decreasing over time (CABRAL et al. 2003). Thus, the flow of the springs was modeled according to the "Maillet Formula" (CASTANY, 1967) (Equation 05), from which we determined the total annual runoff of each spring, which represented the amount of groundwater that was drained from the superficial aquifer.

$$
Q_{t}=Q_{\left.t_{0} \cdot \exp (-\infty x) \cdot t\right)}
$$

For each recharge area, at four points around the observation wells of the superficial aquifer, it was collected undeformed samples of soil at three depths $(0.20,0.50$ and $1.00 \mathrm{~m})$ for the physicohydric characterization of the porous medium, as the determination of curves points of water retention in the soil according to the Mualem-van Genuchten model (GENUCHTEN, 1980), according to Equation 06 and the determination of the soil density.

$$
\theta=\theta_{\text {res }}+\left(\theta_{\mathrm{s}}+\theta_{\mathrm{res}}\right) \cdot\left[1+(\alpha \cdot \psi)^{\mathrm{n}}\right]^{-\mathrm{m}}
$$

where $\theta$ is moisture $\left(\mathrm{cm}^{3} / \mathrm{cm}^{3}\right) ; \theta_{\text {res }}$ is residual moisture $\left(\mathrm{cm}^{3} / \mathrm{cm}^{3}\right) ; \theta_{\mathrm{s}}$ is saturation moisture $\left(\mathrm{cm}^{3} / \mathrm{cm}^{3}\right) ; \psi$ is matrix potential $(\mathrm{KPa})$ and $\alpha, \mathrm{n}$ and $\mathrm{m}$ are parameters of adjustment of the model.

\section{Underground direct recharge}

The direct recharge was estimated by analyzing the variation in the level of groundwater and surface for identification and extrapolation curves recession level of groundwater surface graphically based on the WTF method (HEALY \& COOK, 2002; SCANLONET al., 2002; WAHNFREID \& HIRATA, 2005). The method consists in identifying the periods of recession and abrupt changes in the slope of the level of groundwater as shown on Equation 3.

The value of $S_{y}$ (Equation 3) can be obtained by Equation 07:

$$
\mathrm{S}_{\mathrm{y}}=\mathrm{n}-\mathrm{S}_{\mathrm{r}}
$$

$\mathrm{zn}$ which, $\mathrm{n}$ is the porosity, and $\mathrm{Sr}$ is the specific retention of the soil. The specific retention $(\mathrm{Sr})$ expresses the amount of water that is retained in the soil after being drained by gravity.

Equation 07 can be rewritten with the data obtained from the curve retaining water in soil (Paiva, 2006):

$$
\mathrm{S}_{\mathrm{y}}=\mathrm{P}-\theta_{\mathrm{cc}}
$$

where $\mathrm{P}$ is the soil porosity, and $\theta_{\mathrm{cc}}$ is the moisture in the field capacity.

To obtain the specific yield of the aquifer $\left(S_{y}\right)$ according to Equation 08, the value of soil moisture corresponding to the concept of field capacity at each curve of water retention in the soil were obtained as the humidity value corresponding to the inflection point of the curve of water retention in the soil according to the model proposed by DEXTER (2004): 


$$
\theta_{\mathrm{cc}}=\theta_{\mathrm{res}}+\left(\theta_{\mathrm{s}}-\theta_{\mathrm{res}}\right) \cdot\left[1+\frac{1}{\mathrm{~m}}\right]^{\mathrm{m}}
$$

The porosity was obtained using the following equation:

$$
P=1-\frac{P_{\mathrm{E}}}{P_{\mathrm{p}}}
$$

where $\rho_{\mathrm{g}}$ is the global density and $\rho_{\mathrm{p}}$ is the particle density obtained through the volumetric flask method.

Thus, obtained the moisture value at field capacity and porosity and after calculating specific yield $\left(S_{\mathrm{y}}\right)$ from Equation 08 for each point, at each depth for each one of the recharge areas, it was made an average to represent the specific yield $\left(S_{y}\right)$ in each one of these areas.

After obtaining the specific yield $\left(S_{\mathrm{y}}\right)$, Equation 03 can be applied to each individual elevation of the water level, determining an estimate of the direct recharge.

\section{Deep recharge}

The proposed method for estimating the deep recharge assumes the volume control of the water balance as being the saturated soil region of the spring recharge area (Figure 3). The entry system will be given by direct recharge $\left(R_{d}\right)$ estimated by the WTF method. The variation of the underground storage $(\Delta S)$ will be obtained from the variation of the aquifer level from measurements of the monitoring wells. The system outputs are the base drain $\left(q_{b}\right)$ and the deep recharge $\left(R_{p}\right)$. The deep recharge will be the equation residue:

$$
\mathrm{R}_{\mathrm{p}}=\mathrm{R}_{\mathrm{d}}-\mathrm{q}_{\mathrm{b}}+\Delta \mathrm{S}
$$

Equation 11 does not consider the evaporation of ground water and pumping, because the evaporation of ground water is assumed to be negligible, and as there are no wells exploiting underground water in the study area, the pumping rate is zero. The estimate of the change in underground storage $(\Delta S)$ is given from the data levels in monitoring wells and the estimated aquifer specific yield (Sy) expressed by Equation 12 (WENDLAND et al., 2007):

$$
\Delta \mathrm{S}=\left(\mathrm{h}_{\mathrm{i}}-\mathrm{h}_{\mathrm{i}-1}\right) \cdot \mathrm{S}_{\mathrm{y}}
$$

in which, $h_{i}$ e $h_{i-1}$ correspond, respectively, to changes in the level of groundwater between two consecutive readings.

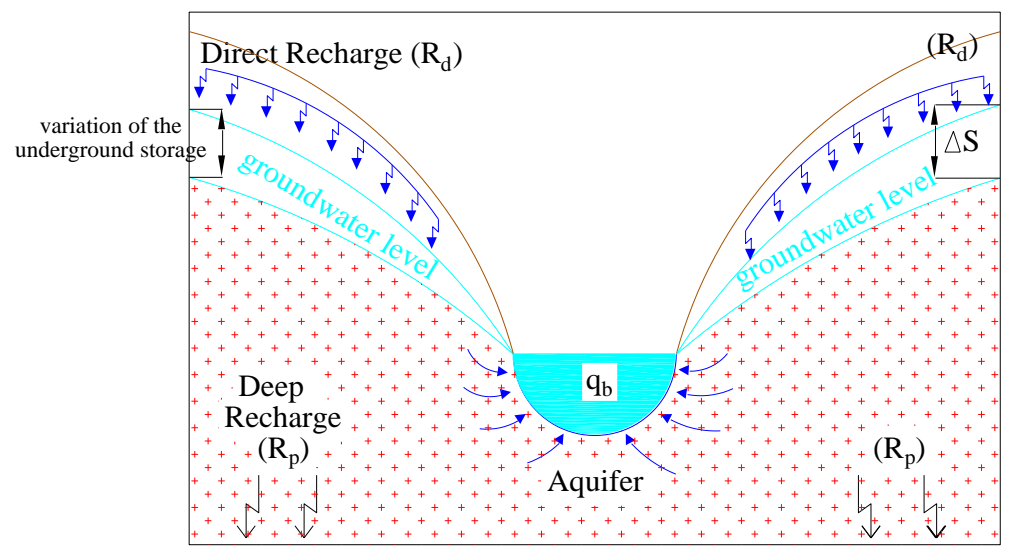

FIGURE 3. Control volume for groundwater balance, where $R_{d}$ is the direct recharge $\left(L^{-1}\right), R_{p}$ is the deep recharge $\left(\mathrm{LT}^{-1}\right) ; \mathrm{q}_{\mathrm{b}}$ is the base flow of the effluent drained $\left(\mathrm{LT}^{-1}\right), \Delta \mathrm{h}$ is the difference between the peak increase and the lowest point of the curve of recession history (L) (WENDLAND et al., 2007). 


\section{RESULTS AND DISCUSSION}

\section{Changes in underground water level}

Through the graphs representing the average level of the superficial aquifer in each superficial aquifer recharge area, it was made identifications and extrapolations of recession curves in the aquifer level, quantifying the changes in the average level of the superficial aquifer by the difference between rise peak and the lowest point of the antecedent recession curve extrapolated until the instant of the peak (Figures 4, 5, 6 and 7). The recession curve shown in magenta is the projection of the level of observation well if there was no elevation of the same.

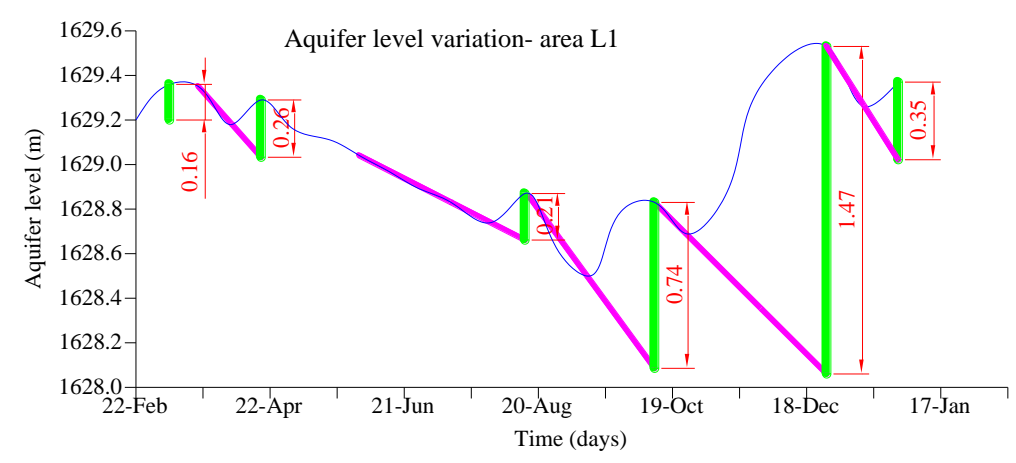

FIGURE 4. Superficial aquifer average level L1 area, showing the water level $(\Delta \mathrm{h})$ variation measures in relation to the recession curves.

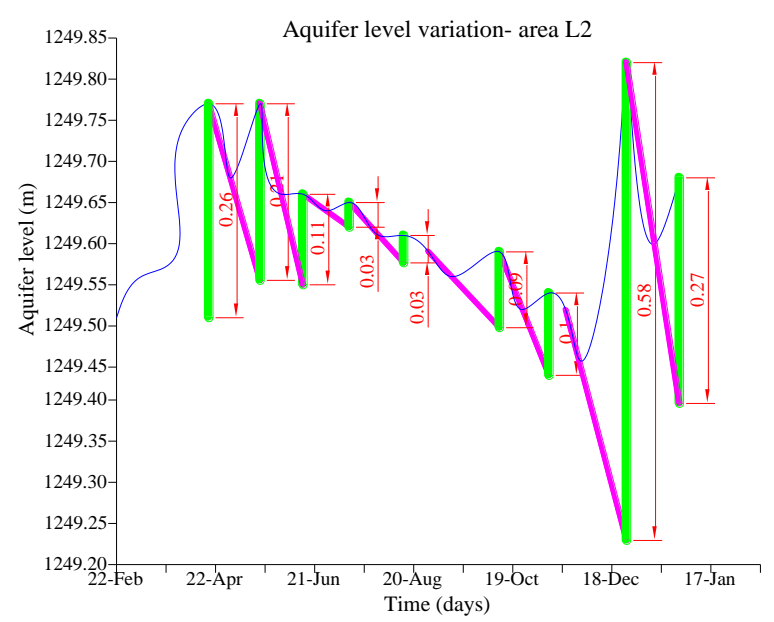

FIGURE 5. Superficial aquifer average level L2 area, showing the water level $(\Delta \mathrm{h})$ variation measures in relation to the recession curves.

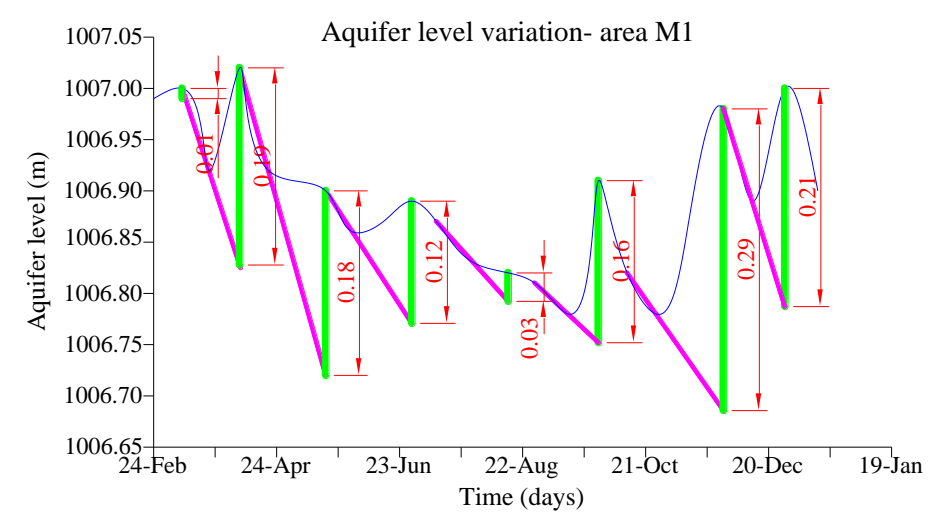

FIGURE 6. Superficial aquifer average level M1 area, showing the water level $(\Delta \mathrm{h})$ variation measures in relation to the recession curves. 


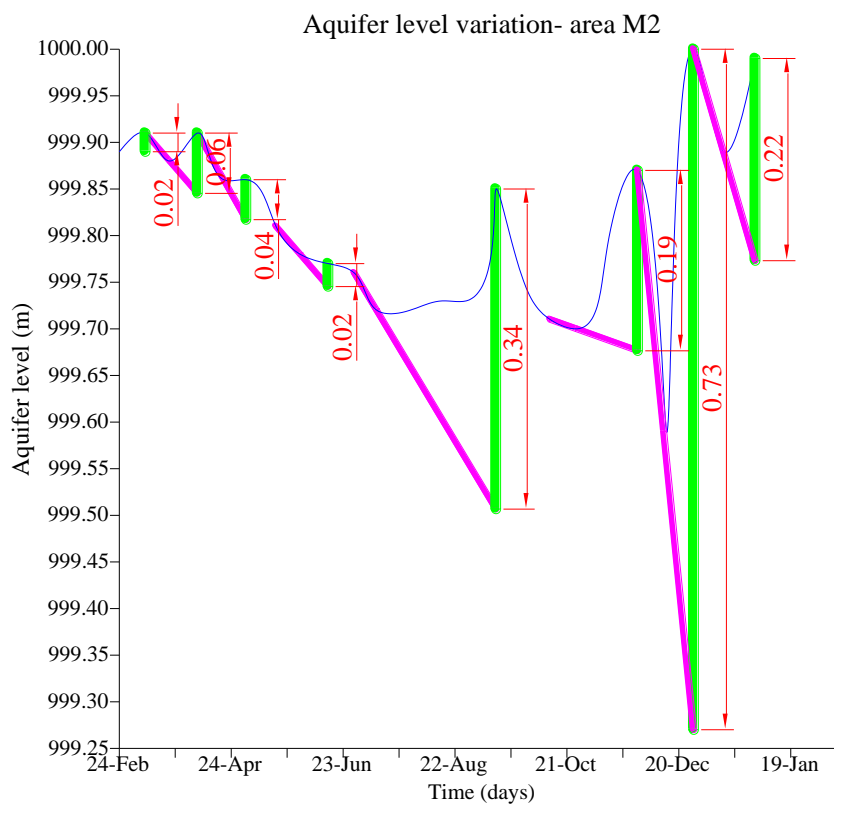

FIGURE 7. Superficial aquifer average level M2 area, showing the water level $(\Delta \mathrm{h})$ variation measures in relation to the recession curves.

The values of the sum of the average changes in the aquifers levels $(\Delta \mathrm{h})$ occurred in the four areas in 2008 were 1,210, 570, 690 and 1.380mm for the recharge areas of the springs L1, L2, M1 and $\mathrm{M} 2$ respectively.

It appears that in the sub-basin of Ribeirão Lavrinhas the sum of level changes in superficial aquifer along the monitored period was higher in L1 recharge area where the vegetation is mostly grassland and a slope of $28.7 \%$. In the sub-basin of Ribeirão Marcela the sum of level changes in superficial aquifer along the monitored period was higher in the M2 recharge area, where the vegetation consists of forest and grassland and the average slope of $25.4 \%$. Therefore, in the subbasin of Ribeirão Lavrinhas, the largest sum of level variations of the superficial aquifer in the area occurred with lower average slope, and in the sub-basin of Ribeirão Marcela, the largest sum of level variations of the superficial aquifer in the area occurred with higher average slope. One explanation for the occurrence of this phenomenon is related to the fact that the wells are leased in an area with small layer of the saturated zone, which can cause a rapid rise in the water table in response to rainfall events. According to (WENDLAND et al. 2007) wells with a thickness of greater saturated zone has a delay in the rise of the water level when compared to wells where the unsaturated zone is lesser.

\section{Estimative of specific yield}

The specific yields average estimated from water retention in the soil for each recharge area can be seen in Table 1 .

TABLE 1. Average values of specific yield obtained from the soil water retention curve.

\begin{tabular}{ccccc}
\hline Area & $\overline{\mathrm{S}_{\mathrm{y}}}$ & & $\boldsymbol{\sigma}$ & $\mathbf{C V}$ \\
\hline L1 & 0.107 & 0.027 & 25.07 \\
L2 & 0.109 & 0.019 & 17.46 \\
M1 & 0.125 & 0.019 & 15.33 \\
M2 & 0.086 & 0.016 & 18.18 \\
\hline
\end{tabular}


Analyzing the standard deviation, it can be seen that there is a high concentration of data about the average, and the coefficient of variation is indicating the relative variability of the sample, which is expressed ranging from 15.33 to $25.07 \%$, respectively. The specific yield of free aquifers is virtually equal to the storage coefficient, being the order of the useful porosity of the medium (BARRETO, 2006). Thus, the M1 spring showed the highest specific yield (0.125) and M2 spring showed the lowest (0.086), both located in the sub-basin of Ribeirão Marcela.

\section{Estimative of direct recharge}

The direct recharge estimated by analyzing the superficial aquifer level and extrapolation of recession curves of the aquifer level, based on the WTF method for the year 2008 is presented in Table 2.

TABLE 2. Direct recharge for the monitored period.

\begin{tabular}{lcccc}
\hline Area & L1 & L2 & M1 & M2 \\
$\mathrm{R}_{\mathrm{d}}(\mathrm{mm} /$ year) & 121.11 & 64.62 & 83.99 & 152.46 \\
$\%$ Precipitation & 6.42 & 4.22 & 6.41 & 12.91 \\
\hline
\end{tabular}

It is verified that the direct recharge occurred more intensely in the areas L1 $(121.11 \mathrm{~mm} / \mathrm{year})$ and M2 (152.46mm/year) corresponding to 6.42 and $12.91 \%$, respectively, of precipitation. In the sub-basin of the Ribeirão Lavrinhas, the greater recharge occurred in the area that has the lowest average slope. However, the opposite occurred in the sub-basin of Ribeirão Marcela. Meanwhile, the M2 spring has $48.5 \%$ of its recharge area covered by forest, and this feature provides conditions that favor infiltration, so, even presenting greater slope there was more direct recharge in M2.

\section{Evaluation of the variation of the underground storage}

The variation of the underground storage of water in an aquifer is equal to the variation of water, which occurs when the level of groundwater changes position in relation to the previous level. The evaluation of the change in underground storage was made from the superficial aquifer levels in monitoring wells and estimation of specific yield of the aquifer for the year 2008. Table 3 shows values for each recharge area.

TABLE 3. Groundwater storage variation in the monitored period.

\begin{tabular}{lcccc}
\hline Area & L1 & L2 & M1 & M2 \\
$\mathrm{h}_{\mathrm{i}}-\mathrm{h}_{\mathrm{i}-1}(\mathrm{~mm})$ & -0.66 & 0.04 & -0.08 & -0.18 \\
\hline$\Delta \mathrm{S}(\mathrm{mm})$ & -0.071 & 0.004 & -0.010 & -0.016 \\
\hline
\end{tabular}

The change in underground storage in the period was -0.071 and $0.004 \mathrm{~mm}$ for the spring recharge areas L1 and L2 in the sub-basin of Ribeirão Lavrinhas and -0.010 and $-0.016 \mathrm{~mm}$ for the spring recharge areas M1 and M2 in the sub-basin of Ribeirão Marcela. These values indicate that the water storage at the end of the analysis period was in a lower bound to the beginning of monitoring, except for the nascent L2 where the opposite occurred.

\section{Estimating deep recharge}

Table 4 shows the components involved in underground water balance and its balance, in the evaluated period, where it is verified that the amount of runoff in the studied period was higher than the direct recharge. This fact indicates a situation where the aquifer drain an amount of water greater than the refill, i.e., the deeper groundwater are feeding these springs, a situation that is clear when analyzing the values of deep recharge. 
TABLE 4. Groundwater balance ( $\mathrm{mm})$ for the monitored period.

\begin{tabular}{lcccc}
\hline \multicolumn{1}{c}{ Cycle components } & L1 & L2 & M1 & M2 \\
\hline Direct Recharge $\left(\mathrm{R}_{\mathrm{d}}\right)(\mathrm{mm})$ & 121.11 & 64.62 & 83.99 & 15246 \\
$\Delta \mathrm{S}(\mathrm{mm})$ & -0.07 & 0.00 & -0.01 & -0.02 \\
Annual runoff $(\mathrm{mm})$ & 349.2 & 231.1 & 165.8 & 183.4 \\
Deep Recharge $\left(\mathrm{R}_{\mathrm{p}}\right)(\mathrm{mm})$ & -228.20 & -166.42 & -81.80 & -30.93 \\
\hline
\end{tabular}

In recharge areas of the springs of the sub-basin of Ribeirão Lavrinhas, the deep recharge (one that can effectively recharge the aquifer) was estimated at -228.20 and $-166.42 \mathrm{~mm}$, respectively. In the recharge areas of the springs of the sub-basin of the Ribeirão Marcela, the deep recharge was estimated at -81.80 and $-30.93 \mathrm{~mm}$, respectively, in M1 and M2 areas.

The negative value of deep recharges demonstrates a profound rise situation, where there may be a transfer of water from the saturated zone into the vadose zone, feeding, thus, the base flow of the springs, and in the rainy season these contributions can be compensated by precipitation .

This method is proved efficient, but estimates made by varying the level of the aquifer (underground storage variation and direct and deeps recharges) assume too much importance due to the uncertainties accompanying the estimate of specific yield of the aquifer.

These results confirm the need for long-term studies, since seasonal influences (excessively wet or dry years) cannot be ruled out when it comes to studies of aquifer recharge.

\section{CONCLUSIONS}

The estimative of direct recharge by the WTF method was proved consistent, because the recharge basins under relative field of Latosols (Ribeirão Marcela Basin) were higher than the recharge basins in the area of cambisols (Ribeirão Lavrinhas).

The presence of forest in the recharge area may outweigh the relief slope, providing more direct recharge, even with steep relief springs.

The runoff from the springs in the studied period exceeded the direct recharge, indicating a situation where the saturated zone feeds the vadose zone. This condition signals the need to monitor the levels of aquifers to obtain more conclusive results.

\section{REFERENCES}

BARRETO, C. E. A. G. Balanço hídrico em zona de afloramento do sistema aquífero guarani a partir de monitoramento hidrogeológico em bacia representativa. 2006. 249 f. Dissertação (Mestrado em Hidráulica e Saneamento) - Escola de Engenharia de São Carlos, Universidade de São Carlos, São Carlos.

BERTOL, G. A. Avaliação da recarga anual no aquífero Bauru no município de Araguari, Minas Gerais. 2007. 101 f. Dissertação (Mestrado em Geologia Econômica e Aplicada) - Universidade Federal de Minas Gerais, Belo Horizonte, 2007.

CABRAL, J.; KOIDE, S.; SIMÕES, S. J. C.; MONTENEGRO, S. Recursos hídricos subterrâneos. In: PAIVA, J. B. de; PAIVA, E. M. C. D. de. Hidrologia aplicada a pequenas bacias hidrográficas. Porto Alegre: ABRH, 2003. cap. 9, p. 237-277.

CASTANY, G. Traité pretique des eaux souterraines. 2nd ed. Paris: Dunod,1967. 661 p.

DEXTER, A. R. Soil physical quality part I: theory, effects of soil texture, density, and organic matter, and effects on root growth. Geoderma, Amsterdam, v. 120, n. 3/4, p. 201-214, jun. 2004. 
FAZAL, M. A.; IMAIZUMI, M.; ISHIDA, S.; TAWACHI, T.; TSUCHIHARA, T. Estimating groundwater recharge using the SMAR conceptual model calibrated by genetic algorithm. Journal of Hidrology, London, v. 303, n. 1/4, p. 56-78, mar. 2005.

GENUCHTEN, M. T. van.A closed-form equation for predicting the hydraulic conductivity of unsaturated soils. Soil Science Society of America Journal, Madison, v. 44, n. 1, p. 892-898, may 1980.

HEALY, R. W.; COOK, P. G. Using groundwater levels to estimate recharge. Hidrogeology Journal, London, v. 10, n. 1, p. 91-109, feb. 2002.

MAZIERO, T. A. Monitoramento de água subterrânea em área urbana: aspectos quantitativos. 2005. 85 f. Dissertação (Mestrado em Hidráulica e Saneamento) - Escola de Engenharia de São Carlos, Universidade de São Carlos, São Carlos, 2005.

MELLO, C. R. de. Estudo hidrológico em microbacia hidrográfica com regime de escoamento efêmero. 2003. 133 f. Tese (Doutorado em Solos e Nutrição de Plantas) - Universidade Federal de Lavras, Lavras, 2003.

MENDONÇA, A. S. Balanço hídrico. In: PAIVA, J. B. de; PAIVA, E. M. C. D. de. Hidrologia aplicada a pequenas bacias hidrográficas. Porto Alegre: ABRH, 2003. cap. 6, p. 165-168.

PAIVA, G. P. Estimativa da recarga em uma unidade dentrítica de uma micro-bacia do Rio Piranga (MG). 2006. 129 f. Dissertação (Mestrado em Engenharia Civil) - Universidade Federal de Viçosa, Viçosa, 2006.

SCANLON, B. R.; HEALY, R. W.; COOK, P. G. Choosing appropriate techniques for quantifying groundwater recharge. Hydrogeology Journal, London, v. 10, n. 1, p. 18-39, feb. 2002.

SCHICHT, R. J.; WALTON, W. C. Hidrologic budgets three small watersheds in Illinois. Journal of Hidrology, London, v. 176, n. 1/4, p. 57-77, mar. 1996.

SILVA, A. M.; MELLO, C. R. de; CORREA, M. R.; CURI, N. Estudos hidrológicos sobre o regime de escoamento de bacias de drenagem para o reservatório da UHE de Camargos/CEMIG. Belo Horizonte: CEMIG/ANEEL, 2005. 90 p.

TUCCI, C. E. M.; BELTRAME, L. F. S. Evaporação e evapotranspiração. In: TUCCI, C. E. M. Hidrologia: ciência e aplicação. 4. ed. Porto Alegre: UFRGS/ABRH, 2007. cap. 2, p. 253-287.

WAHNFRIED, I.; HIRATA, R. Comparação dos métodos de estimativa de recarga de aquíferos em uma planície aluvionar na bacia hidrográfica do Alto Tietê (São Paulo). Revista Brasileira dos Recursos Hídricos, Porto Alegre, v. 10, n. 1, p. 15-25, jan./mar. 2005.

WENDLAND, E.; BARRETO, C.; GOMES, L. H. Water balance in the Guarani aquifer outcrop zone based on hydrogeologic monitoring. Journal of Hidrology, London, v. 342, n. 3/4, p. 213-346, Sept. 2007.

ZAKIA, M. J. B. O balanço hídrico, levando-se em conta o sistema solo-planta-atmosfera, de quatro tipos de coberturas vegetais na região de Grão Mogol, MG. 1987. 136 f. Dissertação (Mestrado em Engenharia Florestal) - Escola Superior de Agricultura Luiz de Queiroz, Universidade de São Paulo, Piracicaba, 1987. 